\title{
Common hamster Cricetus cricetus (L., 1758) in the Silesian Voivodeship, South Poland
}

\author{
Katarzyna SKowrońsKA-OCHMANN*, Joanna ZIOMEK** and Agata BANASZEK*** \\ *Upper Silesian Nature Heritage Center; św. Huberta 35, 40-543 Katowice, Poland; \\ e-mail:k.skowronska@cdpgs.katowice.pl \\ **Department od Systematic Zoology, Adam Mickiewicz University; Umultowska 89, 61-614 Poznań, Poland. \\ e-mail: jziomek@amu.edu.pl \\ ***Institute of Biology, University of Białystok; Świerkowa 20B, 15-950 Białystok, Poland, \\ e-mail: banaszek@uwb.edu.pl
}

\begin{abstract}
An inventory of the localities of common hamsters was conducted in the years 2007-2009. It revealed 14 localities of this rodent in 12 communes within the Silesian Voivodeship. The sites are situated in four macroregions: the Silesian Upland ( 7 localities), the Woźniki-Wieluń Upland (3 localities), the Kraków-Częstochowa Upland (1 locality) and the Przedbórz Upland (3 localities). The present western border of the distribution range of the common hamster in Poland is marked by the following places: Kamieńszczyzna (the Wielun Upland), Piekary Ślaskie (the Tarnowskie Góry Hummock) and Chorzów (the Katowice Upland). A comparison of the number of communes currently inhabited by the common hamster with the data from 40 years ago proves a significant reduction in the population of this species (12 communes out of 43) in the Silesian Voivodeship. The common hamster usually occurs in agricultural areas; however, it can also be encountered in home gardens or in allotments. Moreover, populations inhabiting fields extremely isolated by urban infrastructure were discovered (Siemianowice Śląskie, Piekary Śląskie) and they will be constantly monitored.
\end{abstract}

Key words: common hamster, distribution, population decline, South Poland

\section{INTRODUCTION}

The first detailed research concerning the distribution and habitat requirements of the common hamster in Poland was conducted in the years 1957-1970 (Surdacki 1971). Until the 1970s, there were 68 localities of this rodent species within the Silesian Voivodeship. The most numerous reports came from the vicinities of Jaworzno (28 localities), Częstochowa (20) and Zawiercie (13). The rest of the information about the presence of hamsters was gathered from the vicinities of Racibórz (2), Wodzisław (2), Zywiec (2) and Tarnowskie Góry (1) (Surdacki 1971). After 30 years, a new attempt was made to survey the distribution of the common hamster in Poland (Ziomek \& Banaszek 2007). In the 1990s, the reports about the rapid decline of the population of the common hamster in Europe started to appear (Nechay 2000). Since 1999, the Polish population of hamsters has been studied and monitored continuously. The inventory carried out in Poland in the years 1999-2006 revealed that the existing distribution range diminished to $25 \%$ of the former range. Moreover, the inventory found 103 current localities alongside 146 dubious ones, which can be considered as places from which the common hamster vanished after the year 2000 or where there is still a possibility finding the species. Within the Silesian Voivodeship there were 4 current localities: Mokrzesz, Zarębice near Przyrów, Dobraków and Jaworzno-Byczyna, and 4 dubious localities: Kocikowa, Lelów, Rędziny near Częstochowa and Starzyny (Ziomek \& Banaszek 2007). The sites: Wysoka Lelowska (UTM CB-81) and Zarębice near Przyrów (UTM CB-92) marked the western limit of the presence of hamsters in Poland. The site near Byczyna (UTM CA-75) was 
the southwesternmost one in Poland. Today the entire Polish population is isolated from hamsters living in Germany, the Czech Republic and Bielarus (Ziomek \& Banaszek 2007). The hamster was abundant throughout the territories of the Czech Republic and Slovakia, where large clusters were reported. The present status of the hamster in these countries is unknown (Stubbe \& Stubbe 1998, Nechay 2000; Ziomek \& Banaszek 2008).

The increase in interest in the hamster resulted in an initiative undertaken by scientific circles and institutions that deal with nature conservation. Therefore, in some areas a great deal of effort was put into a long-term and thorough investigation of arable fields and wastelands. Since 2006 monitoring of the distribution and abundance of the common hamster has been conducted by the Upper Silesian Nature Heritage Center. During the first years of the program the following localities with the presence of hamsters were discovered: Siemianowice Śaskie, Piekary Śląskie, Chorzów, Częstochowa and Targoszyce (Skowrońska 2007). Moreover, a detailed description of the presence of hamsters until the year 2006 on the Częstochowa Upland was drawn up (Skowron et al. 2006).

The common hamster has been a protected species since 1995. Since that year, there have been several fauna and flora studies in which the presence of hamsters in the arable fields of the Silesian Voivodeship have been reported (Świerad 1996, Cempulik et al. 1998, 2000, Balon 1999, 2005, Czylok et al. 2002, Henel 2005).

There are also some unpublished data on the distribution of the hamster in the area of Dąbrowa Górnicza from the 1990s (A. Czylok, unpublished). Furthermore, there is information about the existence of the common hamster in the "Cistercian Landscape Compositions of Rudy Wielkie" Landscape Park, however, without data on the exact locations (Henel 2005).

In order to verify the current distribution range of the common hamster in the Silesian Voivodeship, an inventory of hamster localities was conducted and a list of current and dubious localities from the last 10 years was compiled.

\section{STUDY AREA AND METHODS}

Monitoring of the common hamster was carried out in the Silesian Voivodeship which included areas in the following subprovinces: the Mid-Polish Lowlands, the ŚlaskCzęstochowa Upland, the Małopolska Upland, the Northern Subcarpathians and the Outer Western Carpathians (Kondracki 2002). The voivodeship is characterised by a wide diversity of landscapes.

The voivodeship is the most industrialized region in Poland; however, agriculture and rural areas cover more than half of the voivodeship and, therefore, they play an important role in the economy of the region. It is also the most populated area in Poland with a density of 379 people per $\mathrm{km}^{2}$ (the national average is $122 / \mathrm{km}^{2}$ ) (Public Information Bulletin of the Silesian Voivodeship 2009). Since the 1990s, there has been a big change in the structure of crops. The acreage of arable fields has diminished, whereas, the number of fallow fields has increased by $100 \%$ (the Statistical Office in Katowice 2003). This is still an ongoing process. Nevertheless, despite those significant changes, it is still a potential habitat for the common hamster.

The inventory in the years 2007-2009 included field inspections and questionnaires, which are posted on the website of the Upper Silesian Nature Heritage Center in Katowice. Moreover, the initiative included an educational program which constituted talks on the appearance and habitat of the common hamster, which were given in schools of different levels and profiles. The talks were followed by field excursions conducted individually by classes during which observation forms were filled in. Each new piece of information on the occurrence of hamsters was checked during filed inspections by the authors, based on photographs send by third parties. 


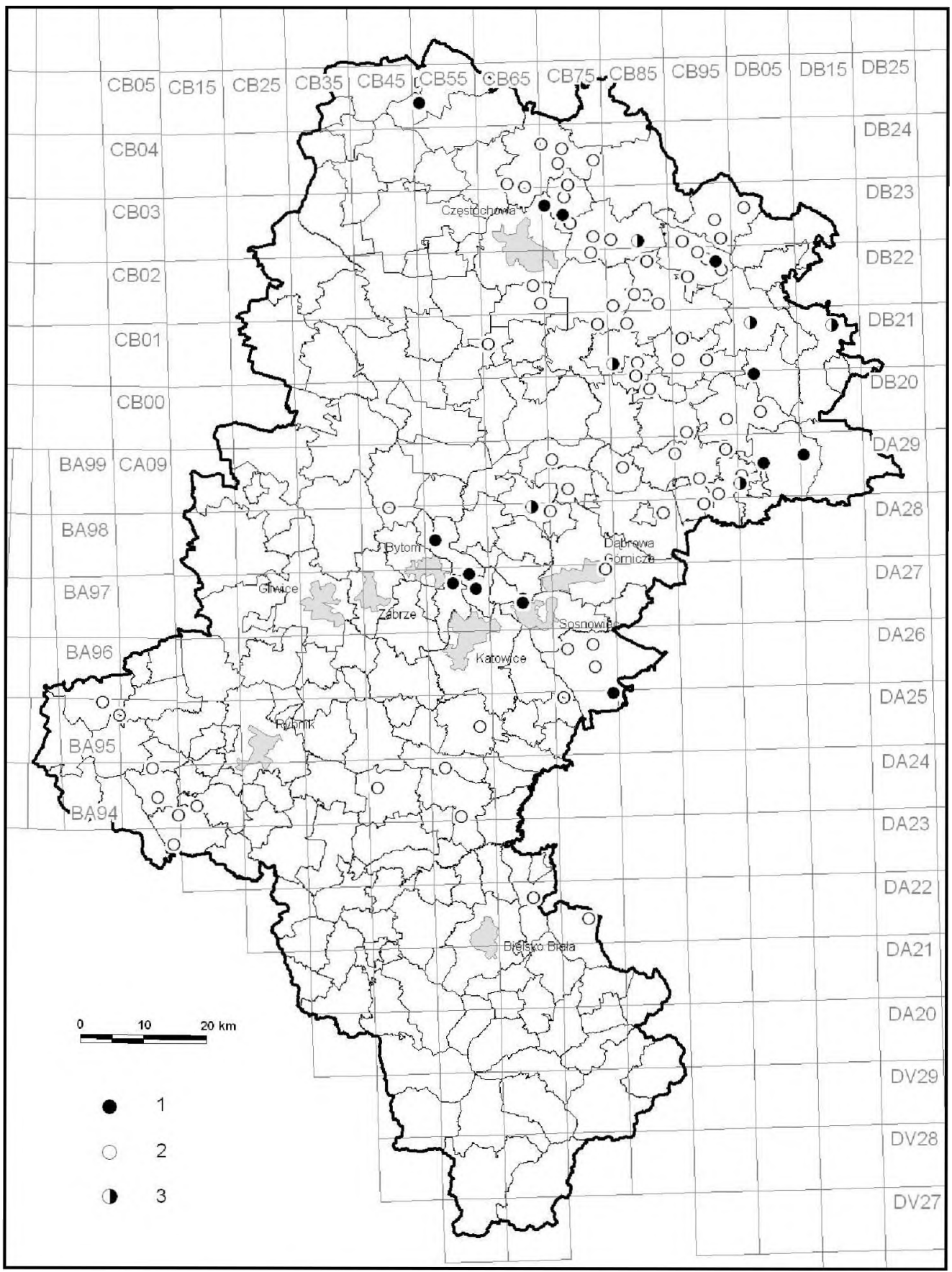

Fig. 1. The distribution of the localities of the common hamster in the Silesian Voivodeship; state for the year 2009; 1 (black circles on the map) - current localities (the localities found in 2007-2009); 2 (open circles) - historical state of the localities, total absence of the hamster; 3 (open-black circles) - dubious localities. 
The data obtained on hamster sites were arranged in the following way (Fig. 1):

A. positive information from questionnaires, field inspections and information based on photographs were treated as denoting current localities (black circles on the map);

B. negative information from questionnaires and/or field inspections were taken to mean the total absence of the hamster from a locality (open circles);

C. positive information from questionnaires not corroborated by field inspections were treated as denoting dubious localities (open-black circles) (Ziomek \& Banaszek 2007).

\section{RESULTS}

The inventory of the common hamster localities that was conducted in the years 2007-2009 revealed the presence of that rodent in 14 localities within 12 communes of the Silesian Voivodeship (Fig. 1). The common hamster inhabited agricultural lands; in addition, it was encountered in house gardens or in allotments. The localities were situated in four macroregions: the Silesian Upland (localities 1-7), the Woźniki-Wielun Upland (localities 810), the Kraków-Częstochowa Upland (locality 11) and the Przedbórz Upland (localities 12-14).

The presence of the common hamster was corroborated in seven localities reported earlier as current (localities: 2, 3, 4, 7, 9, 12,14) and in one reported earlier as dubious (Rędziny: 10).

Six new localities were found: Piekary Śląskie (1), Będzin and Sosnowiec (5-6), Kamieńszczyzna (8), Dzwonowice (11) and Sadowie (13).

One locality reported earlier as current was not corroborated (Mokrzesz - 16). In five localities, classified earlier as dubious, the presence of common hamsters was again not revealed $(15,17,18,19,20)$.

Review of the present localities of the common hamster in the Silesian Voivodeship (Fig. 1).

1. Piekary Ślaskie (UTM CA-58). The localities of the common hamster were found in fields in the center of Piekary Ślaskie, in the vicinity of the Liberation Mound. The rodents had already been observed there at end of the 1980s and the beginning of the 1990s (R. Holewa, unpublished). Dead animals from that population were found in 2005 and 2009 (Sz. Beuch, L. Depa, R. Holewa, unpublished).

2. Dąbrówka Wielka (UTM CA-57). Information referring to the presence of the common hamster (Cempulik et al., 1998) was confirmed by direct observations carried out within the monitoring program established by the Upper Silesian Nature Heritage Center (Skowrońska 2007). In 2008, the hamster population located in fields of Dąbrówka Wielka was substantiated with photographs (Karetta 2009). The presence of that population was confirmed again in 2009 (K. Skowrońska). At present, Dąbrówka Wielka is under the administration of Piekary Ślaskie. However, it is a typical village area separated from the high-density housing of the town, and it is located in a different UTM square, therefore, the locality was listed separately

3. Chorzów (UTM CA-57). The presence of the common hamster was revealed during the valorization of a projected wildlife-landscape complex "Żabie Doły". It includes several water bodies on the border between Bytom and Chorzów, and adjacent agricultural lands of Chorzów (Dobosz et al. 1993, Cempulik et al. 2000). The hamsters were still monitored in fields in the Maciejkowice district in the following years: 1995-2001 and in 2006 (Skowronska 2007). This population still exists (K. Skowrońska).

4. Siemianowice Slaskie (UTM CA-57). The reports about the presence of the common hamster in the town date back to the 1990s (Balon 1999, 2005). Since 2006 the Upper Silesian Nature Heritage Center has been conducting continuous monitoring of that species (Skowrońska 2007). Research carried out in the years 2006-2009 showed a compact 
distribution range in the arable fields in the Michalkowice district and the Bytków district; the population inhabits a substantial part of arable lands in Bangów and some single sites in Przelajka. Furthermore, the species was observed in some house gardens and allotments in Michalkowice. One of the typical characteristics of the Siemianowice Ślaskie population is that it occurs in more than a dozen areas of arable fields separated from each other by town housing (Skowrońska 2009). The occurrence of hamsters in Siemianowice Śląskie was also described by Szczepański (2009). Field inspections were carried out by school children and other observers (A. Molka, J. Szmidt, unpublished).

5-6. Będzin and Sosnowiec (UTM CA-67). The presence of the common hamster in Będzin was reported from allotments in the Małobądz district in 2006 (W. Krawczyński, unpublished). In September 2008 a dead specimen was found in the vicinity of the allotments (R. Gwoźdź, unpublished).

In the years 2005-2009 the presence of the common hamster was noticed in the same allotments complex, but located in Sosnowiec (K. Mazur, W. Kaczmarek, unpublished).

7. Jaworzno (UTM CA-75). The common hamster was reported in Byczyna, an agricultural district of Jaworzno, in 2003 (Ziomek \& Banaszek 2007). In 2009 the locality was still active; moreover, new sites with hamsters were found in neighbouring areas: Jaworzno-Jeziorki and Cezarówka (J. Ziomek). Additionally, one abandoned hamster burrow was encountered in Jaworzno-Ciężkowice, a distant place from the ones mentioned above, in 2006. However, farmers no longer report any hamster activity in that locality. Further field inspections in $2007-$ 2009 did not provide any data on hamsters' activity (J. Ziomek).

8. Kamieńszczyzna (UTM CB-55). Popów commune. In May of 2009, a hamster's burrow was found in a fallow field surrounded by arable fields (P. Hermański - unpublished, substantiated with photographs).

9. Częstochowa (UTM CB-73). An observation of a common hamster and its burrow in arable fields was conducted in the Rząsawy district in May 2006 (Skowrońska 2007). In 2009 the presence of hamsters in that area was confirmed (K. Skowronska).

10. Rędziny near Częstochowa (UTM CB-73). The locality is reported as dubious (Ziomek $\&$ Banaszek 2007). The occurrence of hamsters was confirmed in 2009 when they were observed in small fields located amid a complex of detached houses (J. Ziomek). Nowadays, the building development in that place resembles town housing. The majority of fields lie fallow.

11. Dzwonowice (UTM DA-09). Pilica commune. In 2009 three hamster mounds were found on a high baulk (J. Ziomek).

12. Zarębice (UTM CB-92). Przyrów commune. This locality was found in 2005 (Skowron et al. 2006). In the following years, a series of trapping sessions were carried out in that locality. The common hamster is currently present there, however the population is not numerous (J. Ziomek).

13. Sadowie (UTM DB-00). Irządze commune. In 2009 a single hamster burrow was found in a 4-ha wheat field (J. Ziomek).

14. Dobraków (UTM DA-19). Pilica commune. In 2005 three hamster burrows were reported in a rye field (Ziomek \& Banaszek 2007). In 2009 the common hamster was still present there (J. Ziomek).

The localities of the common hamster which are stated in the literature from the years 2006-2007 as current or dubious were considered to be dubious when the investigation in 2007-2009 did not confirm the presence of hamsters (Fig. 1). We request continuous monitoring of these localities. 
15. Targoszyce (UTM CA-68). Mierzęcice commune. In 2006 a dead individual was found on a road (Skowrońska, 2007). Field inspections carried out in September 2009 (K. Skowronska) did not prove the presence of the species in that locality.

16. Mokrzesz (UTM CB-83). Mstów commune. In 2005 two old hamster burrows without entrances were found (Skowron et al. 2006, Ziomek \& Banaszek 2007). Two field inspections carried out in 2009 did not confirm the presence of the species in that locality (J. Ziomek).

17. Wysoka Lelowska (UTM DB-81). Zarki commune. In 2005 there was only one burrow reported (Skowron et al. 2006). Inventories conducted in 2006-2009 did not confirm the presence of the species in that locality (J. Ziomek).

18. Lelów (UTM DB-01). Lelów commune. In 2003 an individual in a wheat field was observed by a farmer (Ziomek \& Banaszek 2007). A field inspection in 2009 did not confirm the presence of the species in fields, but it did confirm its presence in a nearby place called Lgota Błotna, Nakło (J. Ziomek).

19. Starzyny (UTM DB-11). Szczekociny commune. Despite numerous positive interviews with farmers in 2005, no hamster burrows were found in that locality. A field inspection in 2009 did not provide any proof of the existence of the species either. Moreover, field inspections in fields surrounding Psary and Psary-Kolonia did not show any sign of hamster activity (J. Ziomek).

20. Kocikowa (UTM DA-09). Pilica commune. In 2003 a hamster was observed in arable fields (Ziomek \& Banaszek 2007). However, a field inspection in 2005 and 2009 proved to the contrary (J. Ziomek). Farmers claim that the common hamster used to be a numerous species in the fields, but now it is absent.

\section{DISCUSSION}

Fourteen current localities of the common hamster in the Silesian Voivodeship are situated within the distribution range of the species given by Surdacki (1983). Until 1970, there were 68 localities (Surdacki 1971). After 2000 only 4 localities of the hamster have been discovered. The low number of localities detected is probably due to the larger scale of the project i.e. verification of the national distribution range which is less accurate than a regional analysis (Ziomek \& Banaszek 2007). The total number of the localities of the common hamster in the Silesian Voivodeship during the years 1970-2006 was 86. The localities were situated within 43 communes (Surdacki 1983, Dobosz et al. 1993, Świerad 1996, Cempulik et al. 1998, 2000, Balon 1999, 2005, Czylok et al. 2002, Skowron et al. 2006, Skowrońska 2007, Ziomek \& Banaszek 2007). Currently, the localities are situated in 12 communes. The number of the localities and the population abundance of the common hamster differ, both at present and in the past, among different communes. The comparison of the numbers of the communes inhabited by hamsters proves a significant reduction in the abundance of the species in the Silesian Voivodeship over the last 40 years (Fig. 1).

The present western border of the common hamster distribution range in Poland is marked by the following places: Kamieńszczyzna (UTM CB-55; the Wielun Upland), Piekary Ślaskie (the vicinity of the Liberation Mound) (UTM CA-58; the Tarnowskie Gory Hummock) and Chorzów (UTM CA-57; the Katowice Upland). The majority of the localities of the common hamster in the Silesian Voivodeship are threatened. The populations of the hamster are located amid urban areas, and therefore they are exposed to both strong predation pressure and anthropopressure. Moreover, they struggle with the consequences of lower genetic diversity within the populations (Ziomek \& Banaszek 2008).

What can be done to protect the existing localities? Participation of nature protection organizations and institutions of ecological education and, most importantly, the establishment of agricultural reserves are essential in the protection of the common hamster. The Upper 
Silesian Nature Heritage Center together with the authors published an educational brochure "The common hamster - the most colorful mammal of our fields" which is directed to farmers, children and students (Ziomek et al. 2009). The monitoring of the common hamster in Silesian Voivodeship will be continued, and the educational program, which has been carried out for four years now, will bring positive results.

\section{ACKNOWLEDGEMENTS}

The authors wish to express their gratitude to the students of Primary School No. 16 in Piekary Slaskie, and the School Complex No. 1 and High School No. 2 in Siemianowice Slaskie, who took part in the monitoring of the common hamster in Siemianowice Ślaskie and Piekary Sląskie. Moreover, we wish to thank all of the people who provided information about the presence of the common hamster in the Silesian Voivodeship.

We also thank Z. Wieland for the graphic design of the map.

\section{REFERENCES}

BALON A. 1999. Walory przyrodnicze Siemianowic Śląskich. Mentor, Kraków, 122 pp.

BALON A. 2005. Siemianowice Śląskie. Przyrodnicze ścieżki dydaktyczne po przemyslowej części województwa śląskiego. Kubajak, Krzeszowice, 143 pp.

CempulK P., Hadas T., Holeksa K., Kasperek K., KŁys G., Przywara Z. \& SzUlc-Guziak D. 1998. Piekary Śląskie. Przyroda na Górnym Śląsku. Jak zachować jej najcenniejsze wartości? Kubajak, Krzeszowice, 96 pp.

CEMPUlKK P., Dobosz R., KASPEREK-CEMPUliK J., PISzCZEK M. \& PISZCZEK M. 2000. Ścieżka dydaktyczna po zespole przyrodniczo-krajobrazowym Żabie Doly. Progres, Sosnowiec, 48 pp.

CzyloK A., GĄDEK B. \& TyC A. 2002. Przyroda Mysłowic. Przewodnik przyrodniczy po mieście Mysłowice. Wydawnictwo Urzędu Miasta Mysłowice, $143 \mathrm{pp}$.

DoBOSZ R., HolEKSA K, LIS J. \& KŁYS G. 1993. Dokumentacja projektowanego zespołu przyrodniczokrajobrazowego „Żabie Doły”. II. Polskie Towarzystwo Przyjaciół Przyrody ,pro Natura”. Wrocław. (manuscript). $41 \mathrm{pp}$.

HENEL K. 2005. Wykaz kręgowców (plazy, gady, ptaki i ssaki) Parku Krajobrazowego „Cysterskie Kompozycje Krajobrazowe Rud Wielkich". Scripta Rudensia 14: 75-80.

Karetta M. 2009. Polny chomik. Przyroda Polska 4: 16-18.

KONDRACKI J. 2002. Geografia regionalna Polski. PWN, Warszawa, 468 pp.

NECHAY G. 2000. Status of hamsters: Cricetus cricetus, Cricetus migratorius, Mesocricetus Newtoni and other hamster species in Europe. Nature and Environment series. 106. Council of Europe Publishing. Strasbourg. 73 pp.

SKOWRON B., LABOCHA T. \& ŚWIECIAK T. 2006. Occurence of an European hamster Cricetus cricetus in region of the Częstochowa Upland. Chrońmy Przyrodę Ojczystą 62, 4: 94-98. [In Polish, English abstract]

SKowRońsKA K. 2007. Chomik europejski - zagrożony bojownik. Przyroda Górnego Śląska 47: 10-11, 13.

SKOWROŃSKA K. 2009. Populacja chomika europejskiego Cricetus cricetus w Siemianowicach Śląskich (Wyżyna Katowicka, Polska). In: XI Ogólnopolska Konferencja Teriologiczna w Poznaniu „Poznać i ochronić różnorodność ssaków w Polsce": 113-114.

StUBBE M. \& STUBBE A. (eds) 1998. Ökologie und Schutz des Feldhamsters. Halle/Saale. 480 pp.

SURDACKI S. 1971. The distribution and ranges of the European hamster Cricetus cricetus (Linnaeus, 1758) in Poland Annales Universitatis Mariae Curie-Sklodowska, Lublin B, 26: 266-285. [In Polish, English abstract]

SURDACKI S. 1983. Cricetus cricetus (Linnaeus, 1758). In: PUCEK Z. \& RACZYÍsKI J. (eds), Atlas of Polish mammals, pp. 94-100. PWN. Warszawa. 188 pp. [In Polish and English]

SZCZEPAŃSKI W. 2009. Uwarunkowania siedliskowe na stanowiskach chomika europejskiego (Cricetus cricetus) w Siemianowicach Śląskich. Master thesis, Silesian University, Faculty of Earth Science, Departament of Biogeography and Didactics of Geography, manuscript, $85 \mathrm{pp}$.

SWIERAD J. 1996. Valuation of the area of Upper Silesia in relation to the fauna of mammals. In: BUSZMAN B., POPCZYK M. \& WIECZOREK K (eds), Przestrzeń i wartości. Studia i materiały waloryzacji przestrzeni Górnego Śląska. I. pp. 37-50. Fundacja Przestrzeni Górnego Śląska. Katowice. 167 pp. [In Polish, English abstract]

ZIOMEK J. \& BANASZEK A. 2007. The common hamster, Cricetus cricetus in Poland: status and current range. Folia Zoologica 56, 3: 235-242.

ZIOMEK J. \& BANASZEK A. 2008. Chomik europejski. Monografie przyrodnicze. Wydawnictwo Klubu Przyrodników. Świebodzin. 112 pp. [In Polish, English abstract]

ZIOMEK J., BANASZEK A. \& SKOWRONSKA K. 2009. Chomik europejski - najbarwniejszy ssak naszych pól. Centrum Dziedzictwa Przyrody Górnego Śląska, Katowice. 12 pp. 


\section{STRESZCZENIE}

[Chomik europejski Cricetus cricetus (L., 1758) na terenie województwa śląskiego, w poludniowej Polsce]

Inwentaryzacja stanowisk chomika europejskiego przeprowadzona w latach 2007-2009, wykazala występowanie tego gryzonia w 12 gminach województwa ślaskiego, na 14 stanowiskach. Znajdują się one na obszarze 4 makroregionów: Wyżynie Śląskiej (7 stanowisk), Wyżynie Woźnicko-Wieluńskiej (3 stanowiska), Wyżynie Krakowsko-Częstochowskiej (1 stanowisko) i Wyżynie Przedborskiej (3 stanowiska). Aktualnie zachodnią granice występowania chomika europejskiego wyznaczają następujące stanowiska: Kamieńszczyzna (Wyżyna Wieluńska), Piekary Śląskie (Garb Tarnogórski) i Chorzów (Wyżyna Katowicka) (Rys. 1). Porównanie liczby gmin zasiedlonych przez chomiki (zmniejszenie z 43 do 12 gmin) dowodzi znacznego spadku populacji tego ssaka w województwie śląskim na przestrzeni ostatnich 40 lat. Chomik europejski obecny jest na obszarach rolnych, a ponadto spotykany bywa $w$ ogrodach przydomowych oraz na terenie ogródków działkowych. Znaleziono populacje chomika europejskiego zamieszkujące pola silnie izolowane zabudowa miejska (Siemianowice Śląskie, Piekary Śląskie), które będą poddane stalej kontroli. 